poetic, romantic, and human side of Bose, an aspect that, when missed, leads to an undermining of "a multi-faceted personality" (10). Bose and Emilie's favorite place of retreat, the Austrian town of Badgastein, serves as a calming backdrop to the otherwise adventurous life that Bose led for the cause of India's freedom. In making Gandhi and Emilie central to the narrative, Sugata Bose recovers an ethical ground to explain Bose's choices during the war. He argues that Bose's love for his country rivaled only that of Gandhi's, and it came at the cost of his love for Emilie.

The book itself is organized chronologically, closely following Bose's life through his early years, the prolonged periods of confinement, illness, exile, and political successes, including his dramatic escape from house arrest in Calcutta. In two riveting chapters, Sugata Bose details Bose's ingenious escape, his journey to Europe and then back to Asia, the formation of the Indian National Army, and its eventual failure amidst the backdrop of the global stage of the War, all of which truly demonstrate why Bose was an undisputed and resourceful leader of India (180-303). Bose ably concludes the book by providing clinching and convincing evidence of the leader's death (304-321), an exercise that lays the controversy to rest.

In such a must-read book, a quibble I have is the presentation of Bose only as an ardent nationalist. This effort is understandable, given the breadth and richness of Bose's experience in the global stage; however, it is clear that 'His Majesty's Opponent' was more than simply a nationalist. Bose's life, on the contrary, offers a critique of nationalism itself, especially when we consider yet another parallel between him and Gandhi. While Gandhi's project of nationalism began outside the borders of India, he returned home in the early $20^{\text {th }}$ century to finish it. Bose, by contrast, had to leave India in the 1940s to pursue the same passion. Clearly, between the three decades, what one witnessed was not only the downfall of an empire but also a change in the character of nationalism itself. Bose's unmatched life thus offers an alternative starting point to critically reconsider the history of Indian nationalism, a perspective that remains almost hidden in this otherwise formidable book.

Arvind Elangovan

University of Chicago

Timothy Balzer, The Information Front: The Canadian Army and News Management during the Second World War (Vancouver: University of British Columbia Press, 2011).

Referring to the quality of news reporting during the Second World War, 
Canadian news correspondent Charles Lynch recalled, "It's humiliating to look back at what we wrote during the war. It was crap.... We were cheerleaders. I suppose there wasn't an alternative at the time. It was a total war. But for God's sake, let's not glorify our role. It wasn't good journalism, it wasn't journalism at all" (79). While news reporters wanted to inform the Canadian public of what was happening on the frontlines in Europe, censors had to ensure that information valuable to the war effort was not leaked to the enemy. It was here, as a junior ally in the wartime alliance, that the Canadian Army found itself trying to balance the interests of the media against the military and political realities of the times.

Stemming from his Ph.D. dissertation, Timothy Balzer has produced an interesting account of the evolution of the Canadian Army's public relations efforts to both inform and rally support behind the war effort. Well researched in archives in Britain, Canada, and the United States, the book is comprised of two parts: three chapters taking a chronological overview of Canadian news management during the war, and then the second section of case studies looking specifically at the battles of Dieppe, Sicily, and Normandy. It is in the case studies where the book is at its best.

The Allied raid on Dieppe in August 1942 has gone down in Canadian military history as nothing short of a complete debacle. Yet at the time, it was described "as a tactical as well as an experimental success" (91). From a news management stance, however, there is some irony in the fact that the Americans, who contributed only 50 Army Rangers to the mission, played a much greater role in the publicity planning than did the Canadians who supplied the majority of frontline troops. Such was the plight of a junior ally.

While Dieppe did provide some hard-learned lessons on how not to engage the enemy which were picked up on for the future D-Day invasion in June 1944, it was sugar coated for public consumption. As the Canadians moved into battle in Sicily in the summer of 1943, it was really only possible to report on military actions well after the fact as censors deemed it crucial not to divulge troop movements or casualty reports. The fact that security considerations had to remain paramount was not ever in question among the press. Censoring the fact that the $48^{\text {th }}$ Highlanders of Canada had fought at the Battle of Vimy Ridge in 1917 (41), however, was perhaps a bit overzealous. Nonetheless, Balzer makes an important distinction between military security that could save (or compromise) lives, as opposed to "some censorship seemed motivated by a desire to avoid embarrassment" (129). Sometimes cuts were made by censors but more often than not war correspondents quickly understood the rules to which they had to conform and applied a measure of self-censorship when writing their stories. If they did not conform, reporters might find their access to 
information limited, their press credentials could be revoked, or they could even be charged under military law. The case study of Normandy is an interesting one in that it focuses on the coverage of three negative cases - the killing of Canadian prisoners of war, the massacre of Black Watch at Verriéres Ridge, and instances of friendly fire. While the "tendency to obscure and sanitize unpleasant issues continued...," Balzar notes that the Canadian government "demonstrated considerably more caution than did the army about releasing news of two of these incidents" (146). While not wanting to project on a book something the author had not intended to cover, I think this interaction between the Canadian political and military realms could have been developed a bit more throughout.

The book suffers from some of the common ailments when transforming a Ph.D. dissertation into a book: with the choice of organization the chronology section feels a bit stifled because information is being held back for the case studies. It sounds a bit "thesis-ish" in places, and when talking about Verriéres Ridge, it seems written for the specialist, especially when referring to the historiography on The Valour and the Horror which is complex and difficult to distill. Nonetheless, Balzer should be commended for providing a useful addition to the historical literature, if perhaps a little bit too academic in its tone for the average reader.

Michael K. Carroll

Grant MacEwan University

\section{Joan Sangster, Transforming Labour: Women and Work in Post-war Canada (Toronto: University of Toronto Press, 2010).}

In Transforming Labour, Joan Sangster has provided an expansive and impressive inquiry into the experience of working women in Canada in the decades that followed the Second World War. This key period, which saw women move into the paid labour force in record numbers, has been the purview of public and scholarly conjecture rather than detailed archival research—until Sangster's book.

Ambitious in temporal and geographic scope, the overriding strength of Transforming Labour is the extent of Sangster's primary research, as she mines dozens of archival collections to create a remarkably broad yet detailed picture of working women's experiences in postwar Canada. This substantial empirical research is fused with skilful analysis that engages a wide body of theoretical literature, in history as well as sociology, cultural studies, law and society, and gender studies. The product is an important and overdue contribution to the historiography of modern Canada and diverse historical fields: women's and gender history; labour and working-class history; and social, cultural, and political history. 